\title{
Mites Inhabit Fig Trees at Menoufia Governorate with Control of Phytophagous Mites
}

\author{
Safaa M. Abo-Taka; H. M. Heikal and Samah Zakaria \\ Economic Entomology and Agricultural Zoology Dept., Fac. of Agric., Menoufia University, Egypt.
}

\begin{abstract}
In a field survey, Aceria ficus, Tetranychus urticae and the predator, Phytoseius finitimus, were registered on fig trees from mid of March 2013 to mid of January 2014. A. ficus population reached its peak at mid September with mean number of 29.05 individuals/ leaf. T. urticae at the end of August with mean number of 10.9 individuals/ leaf, whereas the predator, $P$. finitimus reached at mid September. For control, the highest reduction percentages in eriophyid mite population occurred when $P$. finitimus was released by 1 predator/3 Eriophyid mite, resulting in reduction of $90.21 \%$. The tested pesticides: Acaristop, Dumper and High point, recorded reduction percentages 88.14,86.84, and $85.06 \%$ in eriophyid mite population, respectively, while red pepper plant extract gave $82.39 \%$. Numbers of $T$. urticae decreased after all levels of release, where the highest decrease was at the level of 1 predator: 3 preys $(0.03,0.8$ individual/ leaf) after 2 and 4 weeks, respectively, when compared with check. The study recommend the efficiency of the predatory mite, P. finitimus at release levels of $1: 3$ and $1: 5$, in addition to red pepper plant extract $10 \%$.
\end{abstract}

Key Words: Aceria ficus, Tetranychus urticae, Phytoseius finitimus, Fig trees, Biological control, Plant extracts.

\section{INTRODUCTION}

One of the major problems that face fig growers in Egypt is how to control fig mites; the bulk of this crop is planted in desert areas, where the water is scare. Thus the dependence on biological control or other methods seems to be the alternative and inevitable solution to control mites especially eriophyids. ALJoboory and AL-Jorany 2011 determined the effect of infestation by the olive bud mite Aceria oleae (Nalepa) and the olive rust mite Tegolophus hassani (Keifer) on some character growth vegetation of olive nurseries and showed that the eriophyid mites had an effect on some character growth of olive nurseries (plant height, branching number, length of branching. The most common phytophagous mites are Aceria ficus Cotte, and Tetranychus urticae. Fig mosaic disease was first described in 1933 from California (Condit and Horne, 1933) and it was suspected that Aceria ficus might transmit the causal agent; Calglayan et al., 2012 proved that Madagascar periwinkle (Catharanthus roseus) can be retained as a new experimental host for fig mosaic virus (FMV) and Aceria ficus appears to be able to transmit FMV from fig to periwinkle plants. Mohanasundaran 1990 identified species belong to genus Aceria from South India on different hosts. In Egypt, many authors studied different genera of eriophyid mite and its hosts. Abou El-Saad and Salem (2011), recorded four phytophagous mites belonging to the three families on fig trees at Assiut, Tetranychidae, Tenuipalpidae and Eriophyidae (order: Acari). (Attiah, 1967 \& 1970; Soliman and Abou-Awad, 1977; Rasmy and Abou-Awad, 1978; Zaher and Abou-Awad, 1980; Zaher, 1984; Osman and Abo-Taka, 1989; and Elsawi, 1993; Abou-Awad et al., 2011; El-Halawany, 2012 and Kamali et al., 2014).
The aim of this work was to study the distribution of both phytophagous and predaceous mites on fig trees from mid March 2013 to mid January 2014, and the effect of two plant extracts, the predator mite Phytoseius finitimus and three pesticides on phytophagous mites.

\section{MATERIALS AND METHODS}

Biweekly samples of 30 old and young leaves were taken randomly from fig trees in Shebin El-Kom region, Menoufia governorate from mid March 2013 to mid January 2014. Samples were transferred to the laboratory for mite examination. Counts and identification of collected mites were done according to Zaher, 1984. Data was statistically analyzed according to CoStat program (2008).

Eriophyid mite, Aceria ficus was observed as a serious pest on fig trees. Three pesticides (Acaristop, High point, and Dumper); two plant extracts (red pepper and garlic); and three levels of the predator mite, Phytoseius finitimus (1 predator / 3 or 5 or 10 preys) were investigated.

\begin{tabular}{lll}
\multicolumn{4}{l}{ I- Pesticides used: } \\
\hline Trade name & Active substance & Recommendation rate \\
\hline Acaristop $50 \%$ SC & Clofentezine $50 \%$ & $40 \mathrm{~cm}^{3} / 100$ liter water \\
\hline Dumper $55 \%$ SC & Fenbutatin oxide & $100 \mathrm{~cm} / 100$ liter water \\
\hline High point $10 \%$ EC & $\begin{array}{l}\text { Abamectin } 1 \%+ \\
\text { Hexythiazox } 9 \%\end{array}$ & $25 \mathrm{~cm} / 100$ liter water \\
\hline
\end{tabular}

\section{II- Plant extracts:}

Aqueous extracts were prepared using powder of red pepper (Capsicum annuum) and garlic (Allium sativum). Dry powder was added to $200 \mathrm{ml}$ autoclaved sabouraud medium before solidification and mixed thoroughly. Sabouraud medium was previously autoclaved with steam under pressure at 
$121{ }^{\circ} \mathrm{C}$ for $20 \mathrm{~min}$., the concentration $10 \%$ was used (Mutwally et al., 2002).

\section{III- Predatory mite:}

Predator release; leaf samples showed the number of Aceria ficus/ leaf, the number of leaves/ tree approximately thus the number of the predatory mite was calculated at three levels of predator were release:
A. 1 predator/ 3 preys
B. 1 predator/ 5 preys
C. 1 predator/ 10 preys

Samples were taken pre and post 2, 5 days and 1 , $2,3,4,5$ weeks, respectively. Phytophagous and predatory mites were counted, the reduction percentages were calculated according to (Fleming and Retnakaran, 1985) by Handerson and Tilton formula.

\section{RESULTS AND DISCUSSION}

The distribution of both phytophagous and predatory mites inhabit fig trees Ficus carica L. in Shebin El-Kom region, Menoufia governorate was studied during the season from mid March 2013 to mid January 2014 followed by leaves fallen.

Data in Table 1 showed that the first appearance of eriophyid mite, Aceria ficus was recorded in mid April, increased gradually reaching its peak in mid September the numbers began decrease gradually until the end of December. On the other hand Tetranychus urticae appearance was earlier than eriophyid mite, where its mean numbers was 0.4 individual/ leaf at the end of March, then increased gradually to reach its peak at the end of August with mean number 10.9 individuals/ leaf, then decreased till the end of November ( 0.4 individual/ leaf). Samples taken during December and January were from $T$. urticae. The predatory mite appeared in few numbers at the end of May (2 individuals/ 30 leaves) reached its peak in mid September then decreased to one individual/ 30 leaves at the end of November. Data statistical analysis showed significant difference between numbers of the eriophyid mite during mid September and other samples except the numbers at the end of August. The highest infestation of tetranychid mite was early than eriophyid by two weeks; while the highest number of the predatory mite Phytoseius finitimus was at mid September, there are significant difference between the highest number of predator (4.1 indiv./leaf) and the numbers of predators taken during different dates of season. In Iran, Arbabi et al., 2006 found that eriophyid mite had its peak during July month, thus it could be necessary
Table (1): Mean numbers of phytophagous and predatory mites inhabit fig trees in Menoufia Governorate

\begin{tabular}{|c|c|c|c|}
\hline $\begin{array}{l}\text { Date of } \\
\text { samples }\end{array}$ & $\begin{array}{l}\text { Aceria } \\
\text { ficus }\end{array}$ & $\begin{array}{c}\text { Tetranychus } \\
\text { urticae }\end{array}$ & $\begin{array}{l}\text { Phytoseius } \\
\text { finitimus }\end{array}$ \\
\hline $15 / 3 / 2013$ & $0.0^{\mathrm{j}}$ & $0.0^{\mathrm{j}}$ & $0.0^{\mathrm{f}}$ \\
\hline $30 / 3$ & $0.0^{j}$ & $0.4^{\mathrm{ij}}$ & $0.0^{\mathrm{f}}$ \\
\hline $15 / 4$ & $0.9^{\mathrm{ij}}$ & $0.2^{\mathrm{ij}}$ & $0.0^{\mathrm{f}}$ \\
\hline $30 / 4$ & $2.0^{\mathrm{ij}}$ & $0.5^{\mathrm{ij}}$ & $0.0^{\mathrm{f}}$ \\
\hline $15 / 5$ & $4.2^{\mathrm{hi}}$ & $1.1^{\mathrm{ij}}$ & $0.0^{\mathrm{f}}$ \\
\hline $30 / 5$ & $8.4^{\mathrm{g}}$ & $2.1^{\mathrm{ij}}$ & $0.06^{\mathrm{f}}$ \\
\hline $15 / 6$ & $12.9^{\mathrm{f}}$ & $2.8^{\mathrm{ie}}$ & $0.06^{\mathrm{f}}$ \\
\hline $30 / 6$ & $19.1^{\mathrm{de}}$ & $3.8^{\mathrm{ge}}$ & $0.1^{\mathrm{f}}$ \\
\hline $15 / 7$ & $22.7^{\mathrm{cd}}$ & $5.6^{\mathrm{cd}}$ & $0.9^{\mathrm{e}}$ \\
\hline $30 / 7$ & $23.7^{\mathrm{bc}}$ & $7.4^{\mathrm{bc}}$ & $0.8^{\mathrm{e}}$ \\
\hline $15 / 8$ & $25.3^{\mathrm{bc}}$ & $9.2^{\mathrm{ab}}$ & $1.1^{\mathrm{e}}$ \\
\hline $30 / 8$ & $26.9^{\mathrm{ab}}$ & $10.9^{\mathrm{a}}$ & $2.4^{\mathrm{c}}$ \\
\hline $15 / 9$ & $29.05^{\mathrm{a}}$ & $7.6^{\mathrm{bc}}$ & $4.1^{\mathrm{a}}$ \\
\hline $30 / 9$ & $23.00^{\mathrm{c}}$ & $5.2^{\mathrm{d}}$ & $3.2^{\mathrm{b}}$ \\
\hline $15 / 10$ & $19.25^{\mathrm{de}}$ & $3.1^{\mathrm{ie}}$ & $3.5^{\mathrm{b}}$ \\
\hline $30 / 10$ & $19.10^{\mathrm{de}}$ & $2.0^{\mathrm{ij}}$ & $1.8^{\mathrm{d}}$ \\
\hline $15 / 11$ & $15.8^{\mathrm{ef}}$ & $0.8^{\mathrm{ij}}$ & $0.03^{f}$ \\
\hline $30 / 11$ & $13.3^{\mathrm{f}}$ & $0.4^{\mathrm{ij}}$ & $0.03^{\mathrm{f}}$ \\
\hline $15 / 12$ & $5.8^{\mathrm{gh}}$ & $0.0^{i}$ & $0.0^{\mathrm{f}}$ \\
\hline $30 / 12$ & $1.9^{\mathrm{ij}}$ & $0.0^{\mathrm{j}}$ & $0.0^{\mathrm{f}}$ \\
\hline $15 / 1 / 2014$ & $0.0^{j}$ & $0.0^{j}$ & $0.0^{f}$ \\
\hline LSD 5\% & 3.62 & 2.8 & 0.32 \\
\hline
\end{tabular}

to control the phytophagous mite before increase of mite infestation and occurrence of damage.

Studying the effect of two plant extracts, three pesticides, and three levels of the predatory mite, Phytoseius finitimus release against the eriophyid mite are shown in Table 2. Samples were taken 2 and 5 days after treatment from all experiments except from release experiments, and then weekly samples were taken for five weeks. Pretreatment samples were taken in mid May 2013. The reduction percentages were higher in pesticides experiment than plant extract to reach $100 \%$ reduction after five days of application in the three pesticides used, while this percentage were higher for red pepper used than garlic. Weekly samples proved that release of (1 predator : 3 preys) recorded the highest reduction percentages for eriophyid mite population with total mean reduction of $90.21 \%$ followed by pesticides application, ( $88.14,86.84$, and $85.06 \%$ for Acaristop, Dumper and High point ), respectively, then spraying red pepper plant extract which recorded $82.39 \%$. This was followed by the second level of release ( 1 predator/ 5 preys) recording $79.72 \%$, garlic plant extract $78.09 \%$ while the level of ( 1 predator: 10 preys) recorded the least total mean reduction 
Table (2): Effect of some control methods on the eriophyid mite, Aceria ficus infested fig trees

\begin{tabular}{|c|c|c|c|c|c|c|c|c|c|c|c|c|c|c|c|c|c|c|}
\hline \multirow{4}{*}{\multicolumn{2}{|c|}{ Treatments }} & \multicolumn{17}{|c|}{ Mean numbers /leaf and reduction \% } \\
\hline & & \multirow{3}{*}{ Pre } & \multicolumn{16}{|c|}{ Post } \\
\hline & & & \multicolumn{2}{|c|}{2 days } & \multicolumn{2}{|c|}{5 days } & \multicolumn{2}{|c|}{ 1week } & \multicolumn{2}{|c|}{ 2weeks } & \multicolumn{2}{|c|}{3 weeks } & \multicolumn{2}{|c|}{ 4weeks } & \multicolumn{2}{|c|}{ 5weeks } & \multicolumn{2}{|c|}{ Average } \\
\hline & & & M. & $\mathrm{R} \%$ & M. & $\mathrm{R} \%$ & M. & $\mathrm{R} \%$ & M. & $\mathrm{R} \%$ & M. & $\mathrm{R} \%$ & M. & $\mathrm{R} \%$ & M. & $\mathrm{R} \%$ & M. & $\mathrm{R} \%$ \\
\hline \multirow{2}{*}{$\begin{array}{l}\text { Plant } \\
\text { extracts }\end{array}$} & $\mathrm{T} 1$ & 8.2 & 1.7 & 82.42 & 0.2 & 98.41 & 1.5 & 89.51 & 1.2 & 94.51 & 5.6 & 82.42 & 11.6 & 67.55 & 15.8 & 61.95 & $5.37 \mathrm{bc}$ & $82.39 \mathrm{ab}$ \\
\hline & $\mathrm{T} 2$ & 7.7 & 2.1 & 76.88 & 0.3 & 97.47 & 1.6 & 88.08 & 2.3 & 88.80 & 7.8 & 73.92 & 13.7 & 59.18 & 14.7 & 62.30 & $6.07 \mathrm{~b}$ & $78.09 \mathrm{ab}$ \\
\hline \multirow{3}{*}{ pesticides } & T3 & 8.7 & 0.7 & 93.18 & 0 & 100 & 0.8 & 94.73 & 1.5 & 93.53 & 4.5 & 86.68 & 9.5 & 74.95 & 11.5 & 73.90 & $4.07 \mathrm{c}$ & $88.14 a$ \\
\hline & $\mathrm{T} 4$ & 8.7 & 0.7 & 93.18 & 0 & 100 & 0.7 & 94.39 & 1.6 & 93.10 & 5.6 & 83.43 & 9.7 & 74.42 & 13.5 & 69.36 & $5.54 \mathrm{bc}$ & $86.84 \mathrm{ab}$ \\
\hline & $\mathrm{T} 5$ & 8.2 & 0.8 & 91.73 & 0 & 100 & 0.8 & 94.15 & 1.8 & 91.77 & 7.2 & 77.40 & 10.3 & 71.18 & 12.8 & 69.18 & $4.81 \mathrm{bc}$ & $85.06 \mathrm{ab}$ \\
\hline \multirow{4}{*}{ Predator } & T6 & 12.2 & - & - & - & - & 0.2 & 99.06 & 1.6 & 95.08 & 4.8 & 89.87 & 7.8 & 85.33 & 11.3 & 81.71 & $5.14 \mathrm{bc}$ & $90.21 \mathrm{a}$ \\
\hline & T7 & 6.8 & - & - & - & - & 0.2 & 98.31 & 2.3 & 87.32 & 6.2 & 76.53 & 9.8 & 66.94 & 10.5 & 69.51 & $5.8 \mathrm{bc}$ & $79.72 \mathrm{ab}$ \\
\hline & T8 & 6.8 & - & - & - & - & 1.8 & 84.82 & 2.8 & 84.56 & 8.1 & 69.34 & 11.3 & 61.88 & 15.7 & 54.41 & $7.94 a$ & $71.00 \mathrm{~b}$ \\
\hline & Control & 7.8 & 9.2 & - & 12.0 & - & 13.6 & - & 20.8 & - & 30.3 & - & 34.0 & - & 39.5 & - & & \\
\hline LSD & & & & & & & & & & & & & & & & & 1.37 & 16.24 \\
\hline $\begin{array}{l}\text { M. }=\text { Mean } \\
\text { T2 }=\text { Garlic } \\
\text { T6 }=1 \text { pred }\end{array}$ & $\begin{array}{l}\mathrm{R} \%=\mathrm{R} \\
\mathrm{T} 3=\mathrm{Aca} \\
\text { ator } / 3 \text { Eri }\end{array}$ & $\begin{array}{l}\text { eductic } \\
\text { ri stop, } \\
\text { phyid }\end{array}$ & mite, & ntage, & & & & $\begin{array}{l}=\text { no sa } \\
=\text { Dum } \\
=1 \text { pre }\end{array}$ & $\begin{array}{l}\text { per, } \\
\text { lator }\end{array}$ & 5Erioph & id mit & & & $\begin{array}{l}\mathrm{T} 1=1 \\
\mathrm{~T} 5=1 \\
\mathrm{~T} 8=1\end{array}$ & Iigh & int, & ta), & \\
\hline
\end{tabular}

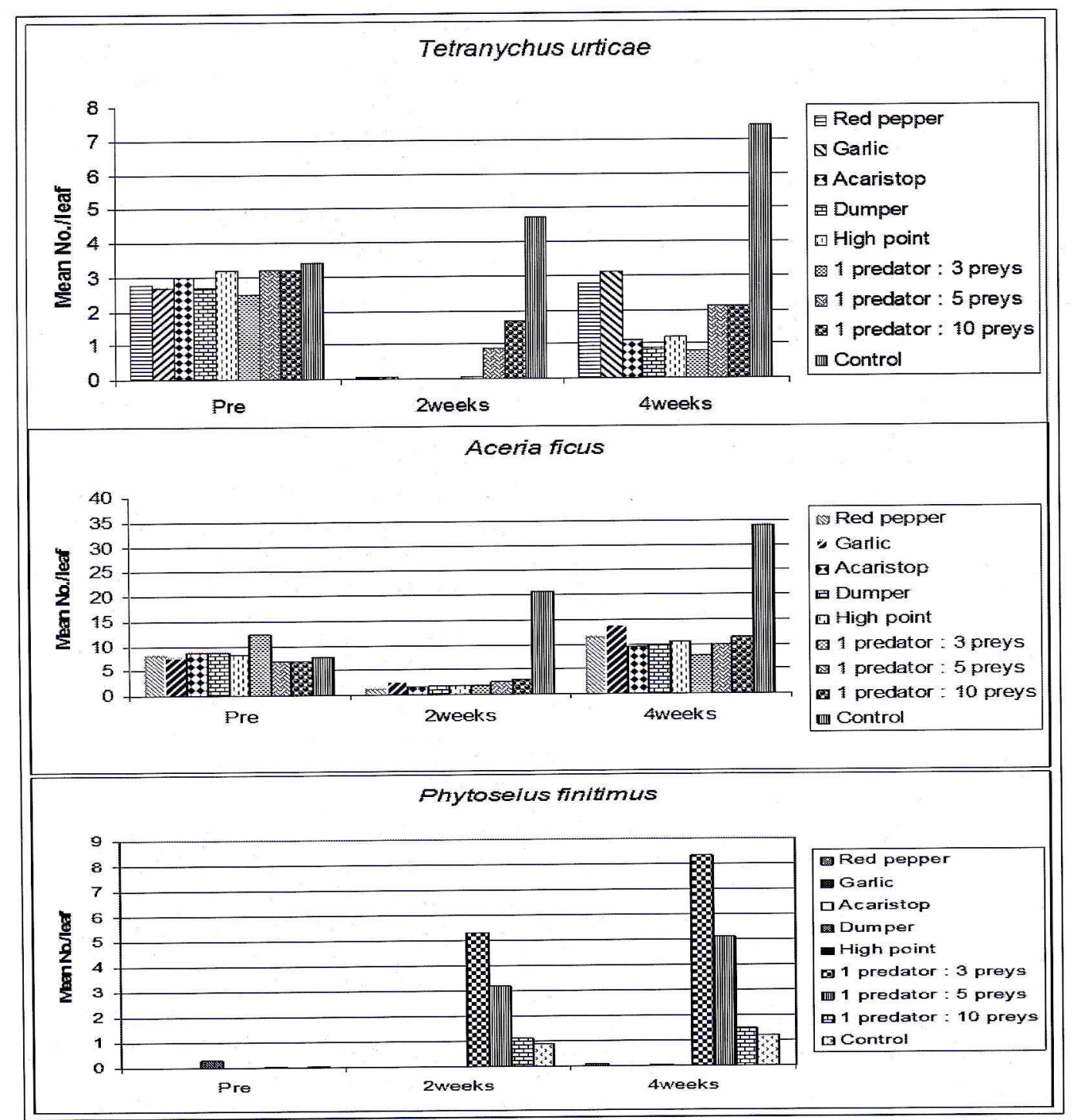

Fig (1): Numbers of both phytophagous and predatory mites before and after two and four weeks of control. 
$71.00 \%$, respectively. Data showed that using the safe release of predatory mite (1predator:3 preys) and spraying of red pepper plant extract with $10 \%$ concentration, reduce the cost of control and are safety to the environment.

Fig. (1) cleared that the numbers of Tetranychus urticae decreased after treatments to its lowest when 1 predator: 3 preys release giving $(0.03,0.8$ individual/ leaf) after 2 and 4 weeks; while check treatment numbers increased to 4.7 and 7.4 individuals/ leaf. The numbers of $T$. urticae ranged between $0: 1.7$ and 0.9: 3.1 individuals / leaf after 2 and 4 weeks in different treatments, respectively.

As predatory mite, pretreatment samples haven't any individuals or 1:2 individuals/ 30 leaves after two weeks of treatment, only the release experiment recorded 5.3, 3.2 and 1.1 individuals/ leaf for the three different levels of release. After four weeks of application only red pepper plant extract samples recorded 0.09 , dumper 0.03 individual/ leaf; while release samples recorded 8.3, 5.1 and 1.5 individuals/ leaf for the three levels of release in compare with control (1.2 individuals/ leaf). This cleared that release of both levels of predatory mite, Phytoseius finitimus 1: 3 and 1: 5 or red pepper plant extracts 10 $\%$ are recommended to control phytophagous mites on fig trees to avoid the undesirable effect of pesticides, to reduce costs of control and to develop the natural predators occurrence.

\section{REFERENCES}

Abou-Awad, B. A. and Elsawi, S. A. 1993. Two new species of eriophyid mites injurious to Acacia trees from Egypt (Acari, Eriophyidae). Deutsche. Entomol. Z., 40(2): 403-406.

Abou El-Saad, A. K. and Salem, A. A. A. 2011. Survey of phytophagous mites on fig trees and their associated predators at Assiut governorate. Minia J. of Agric. Res. and Develop., 31(1): 81-89.

AL-Joboory, H. K and AL-Jorany, R. S. 2011. Effect of infection by the olive bud mite Aceria oleae (Nalepa) and the olive rust mite Tegolophus hassani (Keifer) on some characters growth vegetation of olive nurseries and the efficacy control of some acaricides on their. Diyala Agricultural Sciences Journal, 3(2): 372-364.

Arbabi, M.; Baradaran, P.; Ranjbar, V. 2006. Effect of different fig pruning methods on population of Eriophyes ficus Cotte in Saveh region. Applied Entomology and Phytopathology, 73(2): 37-38.

Attiah, H. H. 1967. Two new species of mites on figs from Egypt (Acarina). Bull. Soc. Ent. Égypte, 51(1): $1-5$.
Attiah, H. H. 1970. New records of eriophyid mites from Egypt (Acarina). Bull. Soc. Ent. Égypte, 54: 43-47.

Caglayan, K.; Elci, E.; Serce C. U.; Kaya, K.; Gazel, M. and Medina, V. 2012. Detection of fig mosaic virus in viruliferous eriophyid mite Aceria ficus. Journal of Plant Pathology, 94 (3): 629-634.

Condit, I. J., Horne W. T. 1933. A mosaic of the fig in California. Phytopathology, 23: 887-896.

CoStat. 2008. CoHort Software 798 Lighthouse Ave. PMB 320. Monterey, CA, 93940, USA. http://www.cohort.com

El-Halawany, A. S. H. 2012. Survey of eriophyid mites on some fruit trees, with re-descriptions of two newly recorded species and a checklist of eriophyid mites in Egypt (Acari: Eriophyoidea). Egypt. Acad. J. Biolog. Sci., 5(2): 205-216.

Fleming, R. and Retnakaran, A. 1985. Evaluating single treatment data using Abott's formula with reference to insecticide. J. Econ. Ent., 78: 11791181.

Kamali, H.; Reza, K. M. and Ali, L. M. 2014. Biology and integrated mosaic disease vector fig eriophyoid mite management Aceria ficus (Acari: Prostigmata) in Razavi Khorasan Province, Iran. 3rd Integrated pest management conference (IPMC), 21-22 Januray, at Keman, Iran.

Mohanasundaram, M. 1990. Studies on the genus Aceria (Acari: Eriophyidae) from South India. Indian J. Acarol., 12(1\&2): 15-88.

Mutwally, H.M.A.; Omar, M.A. and Bedaiwy, M. 2002. Microsporum gallinae growth response to some plant extracts. Faculty of Applied Science, Umm Al-Qura University, Makkah, Kingdom of Saudi Arabia pp.1-8.

Osman, A. A. and Abo-Taka S. M. 1989. Eriophyes acanthus n. sp. from Egypt (Acari: Eriophyoidea: Eriophyidae). Internat. J. Acarol., 15(1): 53-54.

Rasmy, A. H. and Abou-Awad B. A. 1978. A new species of genus Eriophyes from Egypt (Acarina: Eriophyoidea: Eriophydae). Acarologia, 20(3): 385-387.

Soliman, Z. R. and Abou-Awad, A. 1977. Five new species of the genus Eriophyes in the A.R.E. (Acarina: Eriophyoidea: Eriophyidae). Acarologia, 19(4): 668-677.

Zaher, M. A., 1984. Survey and ecological studies on phytophagous, predacious and soil mites in Egypt. I-Phytophagous mites in Egypt (Nile Valley and Delta). Final Report of PL-480 Programme, USA, Project No. EG-ARS 30, Grant No. FG-EG-139, pp. 1-226.

Zaher, M. A. and Abou-Awad, B. A. 1980. A new species and new record of some eriophyid mites in Egypt (Eriophyoidea: Eriophyidae). Acarologia, 21(1): 61-64 